Cluster Analysis of Climate Change Mitigation Behaviours among SMTEs.

Tim Coles, Anne-Kathrin Zschiegner and Claire Dinan

Centre for Sport, Leisure and Tourism Research,

University of Exeter Business School.

Streatham Court, Rennes Drive, Exeter, EX4 4PU. United Kingdom.

(t) +44-1392-724441 (f) +44-1392-722342 (e) t.e.coles@ex.ac.uk 


\title{
A Cluster Analysis of Climate Change Mitigation Behaviours among SMTEs.
}

\author{
Tim Coles, Anne-Kathrin Zsciegner and Claire Dinan
}

(Accepted for publication in Tourism Geographies in 2014.)

\begin{abstract}
Research on tourism and climate change has emphasised the contribution that the sector should make to the effort to reduce and stabilise greenhouse gas emissions. However the tourism sector response on the supply side has been disappointing and highly variable between and within its sub-sectors. This paper addresses the knowledge gap on the willingness and capacity for tourism businesses to mitigate. Innovation is used as the conceptual framework. At the firm level, mitigation requires innovation yet businesses innovate at different rates and hence their ability to contribute towards emissions reductions varies. A Cluster Analysis is presented of over 400 accommodation providers from Southwest England, a major UK destination region. Three distinctive clusters of SMTEs are identified based on how they innovated to mitigate climate change. The smallest (12\%) had introduced a range of process and managerial innovations and was most forward-thinking and active. A second cluster (23\%) had introduced several process innovations but its approach to managerial innovations was both partial and confused. The largest cluster (65\%) had mainly enacted straightforward process innovations but failed to introduce managerial innovations to measure, monitor and act on their environmental performance. Taken together, these data suggest that the contribution from accommodation providers to emissions reductions targets has been at best modest. Moving forward, greater analytical precision is needed if (this part of) the tourism sector is to be widely mobilised towards tackling climate change. Specifically, policy interventions have to be more effectively targeted at business needs and based on a more differentiated view of planned and enacted behaviour changes. One-size-fits-all prescriptions are inappropriate, arguably even counterproductive for encouraging the greatest level of mitigation activity across the widest range of tourism businesses.
\end{abstract}

\section{Keywords}

Tourism, Business, Accommodation, SMTEs, Climate Change, Mitigation, Cluster Analysis. 


\section{Introduction}

Estimates suggest that the tourism sector contributed between 5.2 and 12.5 per cent of human-induced radiative forcing in 2005 (Scott, Hall and Gössling 2012 p.101). This notable sectoral contribution to global warming has precipitated several management and policy responses to engender more sustainable behaviours among travellers (Gössling et al 2009; Barr et al 2011; Dickinson et al 2011; Mair 2011) as well as tourism intermediaries and producers (Hall 2006; Saarinen and Tervo 2006; Gössling 2011). One common issue permeating these studies is how far the full range of actors in the tourism sector is contributing to abating climate change and, in turn, other global environmental changes (Gössling and Hall 2006). After all, 'no major economic sector can expect to remain exempt from making significant emissions reductions as the world economy decarbonizes over the next 25 years' (Scott et al 2010 p.395). Rather, for the greatest reductions in emissions, collective and accumulative action is required now and over time in all aspects of life and sectors of business, including travel and tourism. The biggest differences occur not when behaviour change is the responsibility of the few but when as many individuals, businesses, and organisations as possible take action (Stern 2007).

Nevertheless, for Scott et al (2010) the tourism sector response has been largely disappointing and highly variable between and within sub-sectors. For instance, while aviation is clearly pivotal, contributions from sub-sectors like accommodation should not be overlooked (Scott et al 2010 p.402). The willingness and capacity among tourism businesses to act remains an important knowledge gap (Scott and Becken 2010 p.286). From a business perspective, mitigation requires innovation (Pinske and Kolk 2009; Mowery et al 2009). Indeed, the emergence of the term 'eco-innovation' denotes that sustainable development by necessity requires important long-term changes in technologies, lifestyles, infrastructures and institutions (Rennings 2000). Innovations can be ambitious in scope and radical in nature or they can also be quite modest modifications and incremental changes (Schumpeter 1939). Businesses innovate at different rates (Tidd and Bessant 2009). Through this conceptual lens, this paper examines the extent to which variations exist in climate change mitigation behaviours among accommodation providers in a major UK destination region. Although a significant constituency of the tourism sector, accommodation providers have not featured 
prominently in studies of mitigation. The paper begins by examining how innovation has featured in tourism discourse, in particular as it relates to environmental management and climate change mitigation among small- and medium-sized tourism enterprises (SMTEs), a large sample of which form the basis for the later analysis.

\section{Tourism, Innovation and Climate Change Mitigation}

The geographies of tourism innovation have been the subject of a burgeoning body of knowledge (Sørensen 2007; Hall and Williams 2008; Hjalager 2010). Schumpeter (1939) distinguishes between inventions and innovations. In essence, inventions are technological breakthroughs which are often the outcome of original scientific research while innovations represent the further development and application of inventions. As Hjalager (2002 p.465) has observed, 'innovation is a rather pragmatic term that can also include minor adaptations of products and services'. When applied to contemporary tourism businesses she notes five main types of innovation. Product innovations comprise new products or services that are developed to the point of being brought to market (Hjalager 2002 p.465) whereas process innovations are enhancements to existing operations, perhaps by new or improved technologies or the re-design or configuration of systems (Hjalager 2002 p.465). Management innovations are changes in the restructuring and reorganisation of human resources to deliver gains. Logistics innovations refer to a reconstitution of external commercial relationships whereas institutional innovations 'go beyond the individual enterprise, representing collaborative and regulatory structures in smaller or larger communities' (Hjalager 2002 p.466).

Through this framework, a range of behaviours may be described as innovations within a sector that relies heavily on continuous development of new value propositions (Weiermaier 2005), for instance through rapidly evolving information technologies (Stamboulis and Skayannis 2003; Vadell and Orfila-Sintes 2008). However, not all firms innovate at the same rate or capitalise upon innovations equally. The operating parameters of firms internally 
(Martinez-Ros and Orfila-Sintes 2009; Orfila-Sintes and Mattson 2009) and externally, for instance as part of tourism networks (Sørensen 2007), play important roles in the precipitation and uptake of innovations. Entrepreneurial culture and attitude (Nybakk and Hansen 2008) as well as human resource management and employee training (Ottenbacher and Gnoth 2005) promote successful service innovation within tourism firms. Several studies have examined the spatiality of innovation and the role of co-production among proximate stakeholders (Sørensen 2007; Mattsson et al 2005; Sørensen and Sundbo 2008) in tourism 'innovation systems' (Hjalager 2010b) facilitating new (place-based) products and offers, and enhanced (destination) competitiveness.

In many cases therefore, innovation has been considered from the perspectives of revenue generation and market share whether related to the firm or the destination as the unit of analysis. In other words, innovation is an essential catalyst in the intractable growth paradigm that characterises the tourism sector globally (Gössling et al 2010; Hall 2011). This emphasis on growth has obscured the fact that innovation is a mechanism for reducing the environmental load of businesses (Gonzalez and Leon 2001; Smerecnik and Andersen 2011). For instance, over the past decade top hotel chains have introduced extensive measures that reduce their environmental impacts and costs simultaneously (Bohdanowicz and Zientara 2012). Such pro-environmental process and managerial innovations have not been as widespread among SMTEs. Hobson and Essex (2001) noted that accommodation providers are constrained from innovating due to costs and a lack of time and expertise. From an analysis of 34 businesses, Vernon et al (2003) argued that limited awareness of their footprint was a major obstacle to small firms taking greater action beyond straightforward measures. Tzschentke et al (2008) observed that, among 30 accommodation providers, greater environmental action was part of a value-driven journey. Personal, socio-cultural and other situational factors determined the pace and direction of travel to more sustainable behaviours. Most recently, Sempaio et al (2012a p.235) have noted that, among 81 entrepreneurs, environmental engagement related to world views, self-efficacy beliefs, context beliefs and orientation Furthermore, implementation of new practices varied with the level of formalisation within the business and the owner/manager's background (Sempaio et al 2012b). 
The implication from this work on SMTEs is that there are important sub-sectoral variations not only in attitudes to climate change but also the action taken to tackle it. This view is endorsed in the few studies specifically on the topic. For example, from a sample of 43 rural tourism businesses in New Zealand, Hall (2006) observed that climate change was considered a potentially long-term problem but in the short-term other business imperatives were more important. Similarly, Saarinen and Tervo (2006) noted that over half of 19 nature-based enterprises in Finland did not believe that climate change exists and will affect future tourism development. As a consequence, such studies help to demarcate the lacuna on tourism business behaviours to mitigate climate change. Like Stern (2007), Scott et al (2011) employ the 'Wedges' metaphor (Pacala and Socolow 2004) as a conceptual device. Simply put, each wedge represents a form of human activity in which mitigation behaviours can -and indeed should- take place: the more wedges making a contribution (i.e. tourism), the more subsectors (i.e. 'wedges within wedges' - aviation, accommodation, attractions) and individual actors (i.e. businesses within wedges within wedges) engaged in mitigation behaviour, the greater the progress and the sooner emissions will be reduced and stabilised at acceptable levels. As Stern (2007) famously argued, delays in responding do not postpone the problems of tackling dangerous climate change but rather exacerbate them. At the most granulated levels of analysis (i.e. within wedges within wedges), there will be groups of actors differentiated by the level of response (i.e. innovation). If the prospects for emissions reduction are to be more accurately appraised, it is necessary to understand both who has taken action and how such businesses may accelerate their progress even further as well as those who -in relative terms- have taken less action and how they may be encouraged to change their behaviours.

Prior studies offer some stark warnings of reticence, unwillingness and inability to act on climate change among SMTEs. This is concerning due to the sector's aspirational targets for cutting greenhouse gas emissions (Scott et al 2011) and the numerical prevalence of SMTEs (Thomas et al 2011). However, by virtue of small sample sizes it is unclear how widespread (in)activity is. Hence, more differentiated views of key sub-sectors like accommodation are needed based on larger surveys focusing on action. As studies of pro-environmental behaviour among citizens demonstrate, there is often a clear difference between intention to act (i.e. motivation) and action, and behaviours are broadly segmented into observable types at which policy interventions may be targeted (Barr et al 2011). Thus, a deeper 
understanding of motivations among SMTEs to take pro-environmental measures is not a faithful proxy for response. Action -or the extent to which process and managerial innovations have been and will be introduced- results in reduced emissions. Hence, in the context of understanding the tourism sector's role in climate change mitigation, not only is innovation a relevant conceptual framework but also it offers a more appropriate focus for exploring likely response trajectories.

\section{Methods}

The existence of variations in behaviour among accommodation providers was investigated as part of detailed empirical research in Southwest England on business practices and plans for climate change mitigation. This sampling frame was chosen because it is a major destination and sustainable tourism had been a long-held policy position before the regional tourist board closed in 2011. Many businesses had voluntarily embraced sustainable development and over a third of (English) members of the Green Tourism Business Scheme (GTBS) -a major accreditation scheme in the UK (Sempaio et al 2012b)- were located in the region. Primary research using a mixed methods strategy was completed in Spring 2010. A large-scale questionnaire survey was first undertaken to develop a wider understanding of mitigation behaviours throughout this sub-sector. Nevertheless, interviews are important to SMTE research because they enable more depth about businesses to emerge (Morrison and Teixeira 2004: 166). Thus, 18 semi-structured interviews were subsequently conducted to elaborate the quantitative findings. On average, the interviews lasted around an hour. In the interests of brevity, the interviewees' voices (i.e. verbatims) have not been included but they corroborate the arguments made in the discussion.

For each business, the questionnaire gathered details on its perceived relationship with the environment, including climate change; its environmental practices; and business operating characteristics. 'Innovation' is not straightforward to observe or measure (Tidd and Bessant 2009; Pikkemaat and Peters 2005). To overcome this, several indexes were used including 
the number and type of innovations, the level of investment in innovations, and the timing of innovations to mitigate climate change. Ostensibly, the research focused on within-firm practices. The questionnaire examined how far each business had introduced a series of general systems (i.e. management innovations) to reduce their environmental loads, including recycling, measuring consumption, target-setting, performance reviews, and procurement of more efficient devices. The businesses also entered when 20 specific devices (i.e. process innovations) had been introduced or were planned. These included well-established or straightforward ideas (such as more efficient boilers, double/triple glazing and loft or cavitywall insulation) alongside several more recent technologies including those requiring a higher level of engagement. Among the latter were renewable energy solutions such as photovoltaic cells, solar-powered water heating, and biomass boilers. Although mitigation is often equated to energy use, this paper followed the IPCC approach (Bates et al 2008) and included water management. Finally, the value of investments in six broad areas of innovation were recorded with the maximum acceptable payback period (table 1).

[INSERT TABLE 1 HERE]

The regional tourist board estimated that 14,970 accommodation providers were operating at the time of the research. For a Confidence Level of 95\% and a Precision Level of 5\%, a sample size of over 390 was necessary (Israel 1992 p.3). It chose 5,000 businesses randomly to which it distributed an online invitation to complete the survey. 417 businesses responded with usable data. After 'bounce backs', delivery failures, and false email addresses, this represented a response rate of $8.9 \%$. The sample comprised micro- and smaller tourism enterprises according to employee numbers and turnover (Table 1). A range of accommodation types responded from bed-and-breakfast establishments (14.1\%) to full service hotels (3.6\%), farmhouses (3.4\%) and general self-catering (27.6\%) and guest accommodation (28.3\%). Larger establishments and members of chains were underrepresented. Quality assurance ratings demonstrated that nearly two-thirds of the businesses were well administered. $65.8 \%$ of the accommodation was graded four-star or above and businesses had been in their current ownership for 10.4 years. Hence, many current owners or managers had been in place since before the launch of the Stern Report in 2006 and had time to introduce a range of mitigation measures, if they had desired. 


\section{Analysis}

The existence of distinctive groups of businesses exhibiting similar intra-group mitigation behaviours was investigated by Cluster Analysis which allows researchers to identify 'heterogeneous groups consisting of homogenous elements' (Franke et al 2009 p. 273). Cluster Analysis is a well-established technique in market research (Mazzocchi 2008), and tourism analysis (Arimond and Elfessi 2001; Becken et al 2003; Frochot 2005; Barr et al 2011). A Two-Step Approach using SPSS version 15 was adopted due to the sample size (Hair et al 2010). In the first step, a hierarchical approach using the Ward Method determined the number of clusters among the 416 businesses that provided sufficient data. The second step used the K-means method determined final cluster membership (Hair et al 2010 p.536, 546). Data on the relative uptake of several basic managerial innovations (i.e. introduction of resource saving devices, setting targets for resource saving, and measuring resource use) which could reduce their environmental load, were used to cluster the businesses (see Table 2). Periodicity of implementation was measured on Likert Scales and the categorical data were standardized. Importantly, these scales measured innovations which most businesses could have introduced if they had so wanted because no systemic barriers had to be overcome. Thus, they served as a further proxy of willingness to integrate other managerial and, more especially, specific process innovations that could contribute even more substantively towards tackling climate change. There is no single 'stopping rule' for determining how many clusters exist within a dataset (Mazzocchi 2008; Hair et al 2010). From an inspection of the amalgamation coefficients, three clusters emerged which were stable (Hair et al 2010 p.540). In keeping with academic best practice, descriptive labels were not used here (Pastor 2010 p52). Non-parametric tests were conducted to ascertain the presence of differences among them.

[INSERT FIGURE 1 HERE]

[INSERT TABLE 2 HERE] 
As Table 2 indicates, there were significant differences among the clusters regarding the way in which constituent businesses managed energy and water. Businesses in Cluster One were concerned about climate change and committed to act by means of measuring, monitoring and modifying energy and water consumption (Table 2). This even extended to renewing the environmental credentials of their energy suppliers regularly but more generally the responsible use of energy and water was very deeply embedded within operations (Table 3). Businesses in Cluster Two were distinctive by virtue that the majority measure water and energy consumption but did little thereafter. Targets were neither set nor reviewed habitually (Table 2), although many professed that they purchase energy- and water-saving devices and enacted measures apparently intended to reduce consumption (Table 3). Finally, businesses in Cluster Three demonstrated a disinterest in, and a failure to introduce managerial innovations in the areas of, monitoring and measuring energy and water consumption (Table 2). However, taken at face value, a large majority of this largest cluster habitually introduced a series of low level pro-environmental measures and acted on energy. Conversely, their records on water and taking more integrated, whole-business approaches were comparatively much weaker (Table 3).

[INSERT TABLES 3 AND 4 HERE]

[INSERT FIGURE 2 HERE]

\section{Cluster One}

Unpacking these data further, the smallest cluster (Figure 1) contained the most advanced and ambitious businesses in terms of their uptake of sustainable business practices in which area they had a relatively longstanding interest (Table 4). They had innovated the most extensively (in comparative terms) and intensively (i.e. invested most financially), yet their plans for further innovation remained strong (Table 4). Newer technologies and deeper approaches had been more enthusiastically embraced among this group than any other (Figure 2): Smart metering featured among $28.8 \%$ of businesses, $42.3 \%$ had appointed an 
environmental manger, $32.7 \%$ used green energy suppliers, and $17.3 \%$ had converted to solar-powered water heating.

[INSERT TABLE 5 HERE]

Businesses in Cluster One were the most concerned about, and committed to tackling, climate change despite (or perhaps because of) the relative progress they had made (Table 4).

Among the three groups they felt strongest that their efforts had not gone far enough and they expressed the greatest concerns about the negative effects of climate change on their businesses (Table 4). Measurement and monitoring was practised most widely. They most frequently reported and forecast decreases not only in bills but also consumption of energy and water (Table 5). They had the keenest eye for costs and their control, not least via their bills. Energy- and water-saving targets were set at least quarterly by $75.0 \%$ and $55.8 \%$ respectively, while $80.8 \%$ and $63.5 \%$ of businesses reviewed the performance of their energy- and water-saving devices respectively with the same periodicity (Table 2). Energy bills as a proportion of total costs were lowest reflecting these initiatives.

[INSERT TABLE 6 HERE]

Over $80 \%$ believed that responding to climate change is the morally right thing to do, and over $70 \%$ recognised the competitive advantages of more responsible environmental management, in particular at a time of soaring bills (Table 6). Tackling climate change featured in the investment plans for two-thirds, while $71.2 \%$ reported that utilities were a major feature in their business planning (Table 4). Environmental management was the thirdmost important priority for businesses in the next three years, the highest status among the clusters. Premises were the principal barrier towards acting on climate change (Table 6). They were mentioned by $53.8 \%$. Just under a half of businesses noted that planning $(48.1 \%)$ and payback periods $(46.2 \%)$ presented difficulties. 


\section{Cluster Two}

Businesses in the second cluster had also made some notable progress. Their interest in sustainable business practices was more recent than those in Cluster One, they had invested in fewer areas, but they reported ambitious plans for the future (Table 4). The most important barrier to further action was length of payback period which was mentioned by two-thirds of businesses (67.4\%, Table 6). This was closely followed by the difficulties associated with planning and premises (both $65.3 \%$ ). A lack of information was claimed to be a problem by $27.3 \%$, while nearly a half $(48.9 \%)$ pointed to the problem of too much conflicting data. Nearly half were concerned about the negative effects of climate change but their commitment to act was lower than Cluster One (Table 4). Interestingly, their perceived response level was higher than businesses in Cluster One. Utilities featured (marginally) more prominently in their future business planning (than for Cluster One) but tackling climate change was less of a priority for their future investment plans (Table 4).

Businesses in Cluster Two were more vulnerable to rising energy and water prices because they lacked systematic approaches to monitoring and measurement. For nearly 90\%, energy bills had remained the same or increased in the previous 12 months, with the same forecast for the next 12 months (Table 5). Over 90\% noted the same situation for water bills. Although bills comprised a marginally lower proportion of costs, monitoring was less welldeveloped than Cluster One. Measuring energy and water consumption by customers was conducted by over $50 \%$ on a quarterly basis or more (Table 2 ). These levels were behind those in Cluster One. However, in most cases businesses in this group did not set targets for energy- or water-saving on a quarterly or more routine basis, nor did they review the performance of their devices (Table 2). This was surprising because it was relatively common practice to buy devices and take measures aimed at making savings (Table 3). A confused and disorganized approach was further in evidence. Water-saving practices were less widespread than energy-saving (Tables 2 and 3). Data were clearly recorded but they were not used in target-setting or reviews. Staff training took place in $60 \%$ of businesses but only $31 \%$ accessed external advice on environmental management (Table 3). 


\section{Cluster Three}

Although the largest cluster, businesses in Cluster Three had innovated least and reported the most modest plans moving forward (Table 4). Their interest in sustainable business practices was the most recent, and their total financial investment in innovation had been the lowest. Monitoring was least undertaken although energy bills comprised the highest proportion of costs $(15.6 \%)$, combined utilities constituted the highest proportion of total costs $(22.2 \%)$, and members of this group least reported or anticipated reductions in energy or water bills and consumption (Table 5).

Recycling was once more relatively widespread (Table 3). Over 50\% had introduced loft insulation, efficient boilers, A-rated appliances, double or triple glazing throughout and water-saving devices (Figure 2). More businesses claimed they had introduced smart metering, environmental managers, solar-powered water heating, and solar panels than in Cluster One. However, penetration was not as deep and it was doubtful as to the extent to which these innovations were being appropriately or optimally used. Premises were the principal barrier to further activity (by $70.6 \%$ of businesses) and, once more, payback periods were a barrier for nearly two-thirds (64.2\%). Planning was less of a hindrance, and was mentioned by just over a half of businesses $(52.4 \%)$. Information was perceived in a similar manner to Cluster Two. Lack of information was problematic for $28.3 \%$, while $46.5 \%$ felt there was too much conflicting data in the public domain.

Businesses in Cluster Three lagged significantly behind Cluster Two in encouraging energy saving among staff and customers, as well as their willingness to conduct training and access external advice on environmental management (Table 3). The biggest contrasts with the other clusters were the failure of businesses in Cluster Three to introduce managerial innovations to manage energy and water use in a more intelligent manner. Target setting, measurement or review for energy- or water- use was routinely overlooked (Table 2). This is despite the fact that some members of this group had invested in newer technologies, as noted above (Figure 2). Nevertheless, the defining feature was a lack of appreciation of the nature and seriousness of the issues for their businesses. The connection between reducing 
(environmental) costs and competitive advantages was weakest. It was as if the businesses in Cluster Three had been oblivious to public debate on climate change (Table 4). They were least concerned that it had negatively affected them, the least committed to act, and the most (erroneously) confident that they had achieved all that they could to respond to climate change. They demonstrated the greatest gap between intention and behaviour. Just over 50\% claimed that they were committed to act although the range and depth of climate-related innovations was most limited.

\section{Discussion}

An uneven process of innovation was evident. There are multiple models of the nature and rate of innovation diffusion among service firms (Tidd and Bessant 2009). Of these, probably the most widely used is the Epidemic Model (Geroski 2000; Meade and Islam 2006; Tidd 2006 p.13). On the basis of the time taken for an innovation to diffuse through a population, five behavioural groups are identified from the resulting normal distribution (Figure 3; Robertson 1967; Meade and Islam 2006). Initial adoption is restricted to a very small group of 'innovators'. Further 'early adapters' introduce it and its upsurge in popularity results in acceptance by the so-called 'early majority'. As the rate of uptake peaks and starts to drop, the 'late majority' implement the innovation and they are followed by a persistent group of 'laggards', the last to introduce it. Taken together, the early and late majorities comprise about two-thirds of the population.

\section{[INSERT FIGURE 3 HERE]}

This model resonates with the dominant logic of climate change mitigation (Stern 2007). Action should not be restricted to 'innovators' or 'early adapters'; rather, innovations for mitigation should have spread to, and be employed by, the majority of businesses while 'laggards' have to be engaged. A three-cluster solution may question the model's 
explanatory value. However, it is epistemologically naïve to believe that there would be a perfect fit between model and observed data. Tidd and Bessant (2009) critique the model as best suited to historical retrospectives; Meade and Islam (2006) have pointed to difficulties in defining the essential differences of, and hence ascribing membership to, the five groups; and in this research businesses were clustered on multiple innovations during the unfolding process of change. In view of these caveats, comparison with the model nevertheless offers several helpful insights. Cluster One innovated more rapidly and significantly different in nature to Cluster Two which, furthermore, differed from Cluster Three. In light of their exhibited behaviours (rather than frequency distribution), arguably the first two clusters may be cast as 'Innovators' and 'Early adopters' respectively. It is unclear whether Cluster Three constitutes the 'early majority', 'late majority' or both because it comprised $64.7 \%$ of the sample (versus $68 \%$ of observations plus or minus one standard deviation from the mean in the idealised distribution). More salient, though, is that time is of the essence for emissions reduction (Stern 2007) and action across Cluster Three trailed well behind the others. Finally, the model suggests there should be a distinctive cohort of 'laggards'. Of course, this term is loosely and relatively defined (Robertson 1967; Tidd and Bessant 2009). A close inspection revealed that no businesses had failed outright to modify their practices or operations. Figure 2 indicates that many process innovations were introduced by businesses in Cluster Three albeit they were not used intelligently (tables 2-5). Hence, the absence of laggards is an indication that they did not respond to the survey.

In fact, Tidd and Bessant's (2009) argue that a single model is unable to account fully for the diffusion of innovation. Rather, explanation of contemporary trends should draw on ideas from all the major models. Here the shape of the frequency distribution (Figure 1) is more reminiscent of the Bass Model. For Tidd (2006 p.13), this distinguishes 'innovators', who do not adopt the tactics of social emulation, from 'imitators', for whom there is an epidemic form of transmission. The result is a skewed S-shaped curve in favour of the latter and it suggests that different marketing processes are needed for the innovators and the subsequent imitators'. The difference between the desire to be imitated versus to learn from others' experiences was most apparent from comparing Clusters One and Three. The former represent Innovators; less than 13\% claimed that they imitated other businesses in their responses to climate change (Table 6). Although the moral case was important, economic performance was coupled with a strong desire for first mover advantage to make their 
businesses stand out. Conversely, over a quarter of businesses in Cluster Three openly declared that they were prepared to imitate others. The interviews suggested that this was mainly through emulating best practice, and they wanted to avert the risk of wasting precious but limited investment capital (Table 1). The fact that only a little under $30 \%$ of firms were concerned about the availability of information juxtaposed against just under a half who were concerned about conflicting information corroborates this (Table 6).

In other words, the Bayesian Model -which interprets inaction as a function of information deficit- offers further clues as to why such businesses lagged behind. Cluster Three reported a shortage of clear, reliable and trustworthy advice. Furthermore, it offers an explanation of some of the similarities between Clusters One and Two (Tables 2-5). According to Tidd and Bessant (2009 p.354), 'potential adopters have different beliefs regarding the value of an innovation' because they conduct trials privately. While Clusters One and Two exhibited similarities in a number of process innovations, the fundamental difference was their valorisation of, and further acting upon, measurement and monitoring. Finally, the Probit Model assumes that 'potential adopters have different threshold values for costs and benefits' and 'know the value of adoption but delay adoption until the benefits are sufficient' (Tidd 2006 p.13). The cluster characteristics suggest different thresholds for action existed (Tables 2-5), paramount among which were payback periods and problems adapting their properties (Table 6). Among Cluster Three the thresholds were set much higher. In a sense, this is not necessarily bad news. The size of the cluster offers the prospect that future diffusion could be relatively rapid should policy interventions and market forces make greater mitigation activity more attractive.

Thus, each model contributes to explaining mitigation behaviours among accommodation providers in Southwest England, and they make it clear that greater analytical precision is vital moving forward. Set against the UK's ambitious targets for emissions reductions (Giddens 2009), the contribution from accommodation providers has been at best modest and will continue to be under 'business as usual'. Deferred action by the majority is risky (Stern 2007) and the prognosis is gloomier if there is a significant, as yet undetected cohort of Laggards. Moreover, current 'one-size-fits-all' UK climate change policy prescriptions (DECC 2010) are designed to mobilise those that have not yet acted; however, they lack the 
differentiation that this evidence demonstrates is vital to stimulating the widest possible action. For instance, further encouragement or dedicated support is lacking for the significant minority that have made more progress. This is a missed opportunity for abatement because such businesses have the capacity to deliver even greater emissions reductions while others are embarking on their 'mitigation careers'.

Future policy interventions must be precisely geared to the types of innovations that different groups of businesses have made and are still yet to make. Introductory information has little relevance to Cluster One. For them, the principal challenge is to harness their hard data to inform future investment decisions on even more advanced process innovations and internal management strategies to maximise the economic and environmental benefits they may accrue. Cluster Two requires more (advanced) support on measurement, monitoring and modifying practice (i.e. further managerial innovation). Finally, a combination of basic managerial and further, deeper process innovations is necessary for Cluster Three. Businesses have to progress beyond the 'low hanging fruits' and 'easy wins' that have characterised their approach for the last decade (Jimenez et al 2001, Vernon et al 2003; Sempaio et al 2012b). They too face the task of conducting more monitoring (i.e. from a basic level) but foremost policy has to challenge their complacency about climate change.

\section{Conclusion}

This paper has examined the extent to which variations exist in climate change mitigation among accommodation providers in the Southwest of England. It has revealed three broad sets of behaviours related to innovation in this regard. Somewhat worryingly, the majority group had made limited progress towards climate change mitigation. Conversely, a small cluster of accommodation providers had innovated much wider and deeper. While a composite analysis would have presented a gloomy prognosis and forecast further delays in the sub-sectoral response to climate change, this more differentiated view suggests that there are some brighter glimmers of progress. Nevertheless, there is much work ahead if small 
businesses in the accommodation sub-sector are to contribute to the sector's ambitious targets. 'Mainstreaming' climate change policy for businesses and across the entire tourism sector has clear limitations. If future policy interventions continue to concentrate exclusively on the majority, they will be of limited relevance to a significant minority. Paradoxically and disappointingly, among this are the businesses that are more positive about acting on climate change, have taken action already, and could make even stronger contributions to emissions reductions and stabilisation if they were appropriately encouraged.

Of course, the wider applicability of case-study research is an important consideration. Here the destination-specific features included the longstanding commitment to sustainable tourism; the response mode for the survey; the absence of larger hotels and members of chains; and the possible non-participation in the survey of what -in the vocabulary of the Epidemic Model- are termed 'Laggards'. Nevertheless, the principal contribution of this regional analysis is to highlight the importance of progressing beyond aggregated results and small sample sizes in empirical work if understanding of the supply side response to climate change is to be deepened further and evidence-based policy is to be fostered. Although motivations for environmental management are relatively well-understood, the full extent to which this intention is translated into behaviour by means of innovation is central to future mitigation and it should not continue to be overlooked. Giddens (2009) concluded that it is time to move beyond the 'why?' of climate change to the 'how?'. This paper suggests that even this is moribund. Rather, if the tourism sector is to play a full role in tackling climate change, it is important to start asking more meaningful questions such as 'what is being done by whom?', even more searchingly 'by when?'. 


\section{References}

Arimond, G. and Elfessi, A. (2001) A clustering method for categorical data in tourism market segmentation research, Journal of Travel Research, 39, pp.391-97.

Barr, S.W., Shaw, G. and Coles, T.E. (2011) Times for (un)sustainability? Challenges and opportunities for developing behaviour change policy, Global Environmental Change 21, pp.1234-1244.

Bates, B.C., Kundzewicz, Z.W., Wu, S. and Palutikof, J.P. (eds.) (2008) Climate Change and Water. Technical Paper of the Intergovernmental Panel on Climate Change (Geneva: IPCC Secretariat).

Becken, S., Simmons, D. and Frampton, C. (2003) Segmenting tourists by their travel pattern for insights into achieving energy efficiency, Journal of Travel Research, 42, pp.48-56.

Bohdanowicz, P. and Zientara, P. (2012) CSR-inspired environmental initiatives in top hotel chains. in: D. Leslie (Ed.) Tourism Enterprises and the Sustainability Agenda across Europe, pp.93-121 (Farnham: Ashgate).

Franke, N., Reisinger, H. and Hoppe, D. (2009) Remaining within-cluster heterogeneity: a meta-analysis of the 'dark side' of clustering methods, Journal of Marketing Management, 25(3-4), pp.273-293.

Frochot, I. (2005) A benefit segmentation of tourists in rural areas, Tourism Management, 26, pp.335-46.

Giddens, A. (2009) The Politics of Climate Change (Cambridge: Polity Press).

Gonzalez, M. and Leon, C.J. (2001) The adoption of environmental innovations in the hotel industry of Gran Canaria, Tourism Economics, 7(2), pp.177-190.

Gössling, S. (2011) Carbon Management in Tourism. Mitigating the Impacts on Climate Change. (London: Routledge).

Gössling, S. and Hall, C.M. (2006) Tourism and Global Environmental Change (London: Routledge).

Gössling, S., Haglund, L., Kallgren, H., Revahl, M. and Hultman, J. (2009), Swedish air travellers and voluntary carbon offsets: towards the co-creation of environmental value?, Current Issues in Tourism, 12(1), pp.1-19.

Gössling, S., Hall, C.M., Peeters, P. and Scott, D. (2010) The future of tourism: a climate change mitigation perspective, Tourism Recreation Research, 35(2), pp.119-130.

Hall, C.M. (2006) New Zealand tourism entrepreneur attitudes and behaviours with respect to climate change adaptation and mitigation, International Journal of Innovation and Sustainable Development, 1(3), pp.229-237. 
Hall, C.M. (2011) Policy learning and policy failure in sustainable tourism governance: from first- and second-order to third-order change?, Journal of Sustainable Tourism, 19(4-5), pp.649-671

Hall, C.M. and Williams, A.M. (2008) Tourism and Innovation (Abingdon: Routledge).

Hair, J.F., Black, W.C., Babin, B.J. and Anderson, R.E. (2010) Multivariate Data Analysis. A Global Perspective. (Upper Saddle River (NJ): Pearson Prentice Hall, $7^{\text {th }}$ edition).

Hjalager, A-M. (2002) Repairing innovation defectiveness in tourism, Tourism Management, 23, pp.465-474.

Hjalager, A-M. (2010a) A review of innovation research in tourism, Tourism Management, 31(1), pp.1-12.

Hjalager, A-M. (2010b) Regional Innovation Systems: the case of Angling Tourism, Tourism Geographies, 12(2), pp.192-216.

Hobson, K. and Essex, S. (2001) Sustainable tourism: a view from accommodation businesses, Service Industries Journal, 21(4), pp.133-146.

Israel, G.D. (1992) Determining Sample Size. University of Florida, Gainesville FL: Program Evaluation and Organizational Development, Florida Co-operative Extension Service, Institute of Food and Agricultural Services (Fact Sheet PEOD-6).

Mair, J. (2011) Exploring air travellers' voluntary carbon-offsetting behaviour, Journal of Sustainable Tourism, 19(2), pp.231-246.

Martinez-Ros, E. and Orfila-Sintes, F. (2009) Innovation activity in the hotel industry, Technovation, 29, pp.632-641,

Mattsson, J., Sundbo, J. and Fussing-Jensen, C. (2005) Innovation systems in tourism: the roles of attractors and scene-takers, Industry and Innovation, 12(3), pp.357-381.

Mazzocchi, M. (2008) Statistics for Marketing and Consumer Research (London: Sage).

Morrison, A. and Teixeira, R. (2004) Small business performance: a tourism sector focus, Journal of Small Business and Enterprise Development, 11(2), pp.166-173.

Mowery, D.C., Nelson, R.F. and Martin, B. (2009) Technology Policy and Global Warming. Why New Policy Models are Needed. (London: NESTA - Provocation 10: October 2009).

Nybakk, E. and Hansen, E. (2008) Entrepreneurial attitude, innovation and performance among Norwegian nature-based tourism enterprises, Forest Policy and Economics, 10, pp.473-479.

Orfila-Sintes, F. and Mattson, J. (2009) Innovation behaviour in the hotel industry, Omega, 37, pp.380-394.

Ottenbacher, M. and Gnoth, J. (2005) How to develop successful hospitality innovation, Cornell Hospitalty and Restaurant Administration Quarterly, 46(2), pp.205-222.

Pacala, S. and Socolow, R. (2004) Stabilization wedges: solving the climate problem of the next 50 years with current technologies, Science, 305 (5686), pp.968-97. 
Pastor, D.A. (2010) Cluster analysis, in: G.R. Hancock and R.O. Mueller (Eds.) The Reviewer's Guide to Quantitative Methods in the Social Sciences, pp.42-54 (New York, Routledge).

Pikkemat, B. and Peters, M. (2005) Towards the measurement of innovation - a pilot study in the small and medium sized hotel industry, Journal of Quality Assurance in Hospitality and Tourism, 6(3\&4), pp.89-112.

Pinske, J. and Kolk, A. (2009) International Business and Global Climate Change (London: Routledge).

Rennings, K. (2000) Redefining innovation - eco-innovation research and the contribution from ecological economics, Ecological Economics, 32, pp.319-332.

Robertson, T.S. (1967) The process of innovation and the diffusion of innovation, Journal of Marketing, 31 pp.14-19

Rogers, E.M. (1962) Diffusion of Innovations (New York: Free Press of Glencoe).

Schumpeter, J. (1939) Business Cycles. A Theoretical, Historical and Statistical Analysis of the Capitalist Process (New York, London: McGraw-Hill).

Saarinen, J. and Tervo, K. (2006) Perceptions and adaptation strategies of the tourism industry to climate change: the case of Finnish nature-based tourism entrepreneurs, International Journal of Innovation and Sustainable Development, 1(3), pp.214-228.

Scott, D. and S. Becken (2010) Adapting to climate change and climate policy: progress, problems and potentials, Journal of Sustainable Tourism, 18(3), pp.283-295.

Scott, D., Hall, C.M. and Gössling, S. (2012) Tourism and Climate Change. Impacts, Adaptation and Mitigation. Abingdon: Routledge.

Scott, D., Peeters, P. and Gössling, S. (2010) Can tourism deliver its 'aspirational' greenhouse gas emission reduction targets?, Journal of Sustainable Tourism, 18(3), pp.393-408.

Sempaio, A.R., Thomas, R. and Font, R. (2012a) Why are some engaged and not others? Explaining environmental engagement among small firms in tourism, International Journal of Tourism Research, 14, pp.235-249.

Sempaio, A.R., Thomas, R. and Font, X. (2012b) Small business management and environmental engagement, Journal of Sustainable Tourism, 20(2), pp.179-193.

Smerecnik, K.R. and Andersen, P.A. (2011) The diffusion of environmental sustainability innovations in North American hotels and ski resorts, Journal of Sustainable Tourism, 19(2), pp.171-196.

Stamboulis, Y. and Skayannis, P. (2003) Innovation strategies and technology for experience-based tourism, Tourism Management, 24, pp.35-43.

Stern, N. (2007) The Economics of Climate Change: the Stern Review (Cambridge: Cambridge University Press). 
Sørensen, F. (2007) The geographies of social networks and innovation in tourism, Tourism Geographies, 9(1), pp.22-48.

Sørensen, F. and Sundbo, J. (2008) Public-private Co-innovation. A Natural Experiment of Open and User Driven City Innovation. Unpublished Working Paper (ICE-Project 2008:01). (Roskilde University and Aalborg University).

Tidd, J. (2006) A Review of Innovation Models. Discussion Paper 1. Online document. Available from: http://www3.imperial.ac.uk/portal/pls/portallive/docs/1/7290726.PDF [Last accessed: 14/01/09]

Tidd, J. and Bessant, J. (2009) Managing Innovation. Integrating Technological, Market and Organizational Change (Chichester: J. Wiley \& Sons, $4^{\text {th }}$ edition).

Tzschentke, N.A., Kirk, D. and Lynch, P.A. (2008) Going green: decisional factors in small hospitality operations, International Journal of Hospitality Management, 27, pp.126133.

Vadell, J.G.B. and Ofila-Sintes, F. (2008) Internet innovation for external relations in the Balearic hotel industry, Journal of Business and Industrial Marketing, 23(1), pp.7080 .

Weiermaier, K. (2005) Prospects for innovation in tourism: analysing the innovation potential throughout the tourism value chain, Journal of Quality Assurance in Hospitality and Tourism, 6(3\&4), pp.59-72. 


\begin{tabular}{|l|l|}
\hline Business Attribute & Value \\
\hline Average number of employees (full-time equivalents) & 3.2 \\
\hline Average turnover in 2009 (£k) & 60 \\
\hline \% for whom turnover decreased in last 12 months & 20.3 \\
\hline Average occupancy in 2009 (\%) & 53.4 \\
\hline Average number of bedspaces* & 15.9 \\
\hline \% Accommodation Graded 3-Star & 21.3 \\
\hline \% Accommodation Graded 4-Star & 55.7 \\
\hline \% Accommodation Graded 5-Star & 10.1 \\
\hline Average date business established & 1980 \\
\hline \% of businesses operating before 1980 & 34.9 \\
\hline Average length of business in current ownership (years) & 10.4 \\
\hline Average date premises first built (year) & 1919 \\
\hline \% of premises built after 1980 & 11.0 \\
\hline Average number of innovations made in last 10 years & 8.2 \\
\hline Average number of planned innovation in next year & 3.2 \\
\hline Average total investment over past 10 years (£k)* & 12.6 \\
\hline Average proportion of costs as energy bills (\%) & 14.8 \\
\hline Average proportion of costs as water bills (\%) & 6.8 \\
\hline
\end{tabular}

* 5\% trimmed mean (refers to roof insulation, wall insulation, efficient (water, central) heating systems, renewable technologies (solar, wind, water), efficient (i.e. A-rated) appliances, and double/triple glazing.

Table 1. Selected characteristics of tourism businesses in survey. Source: authors 


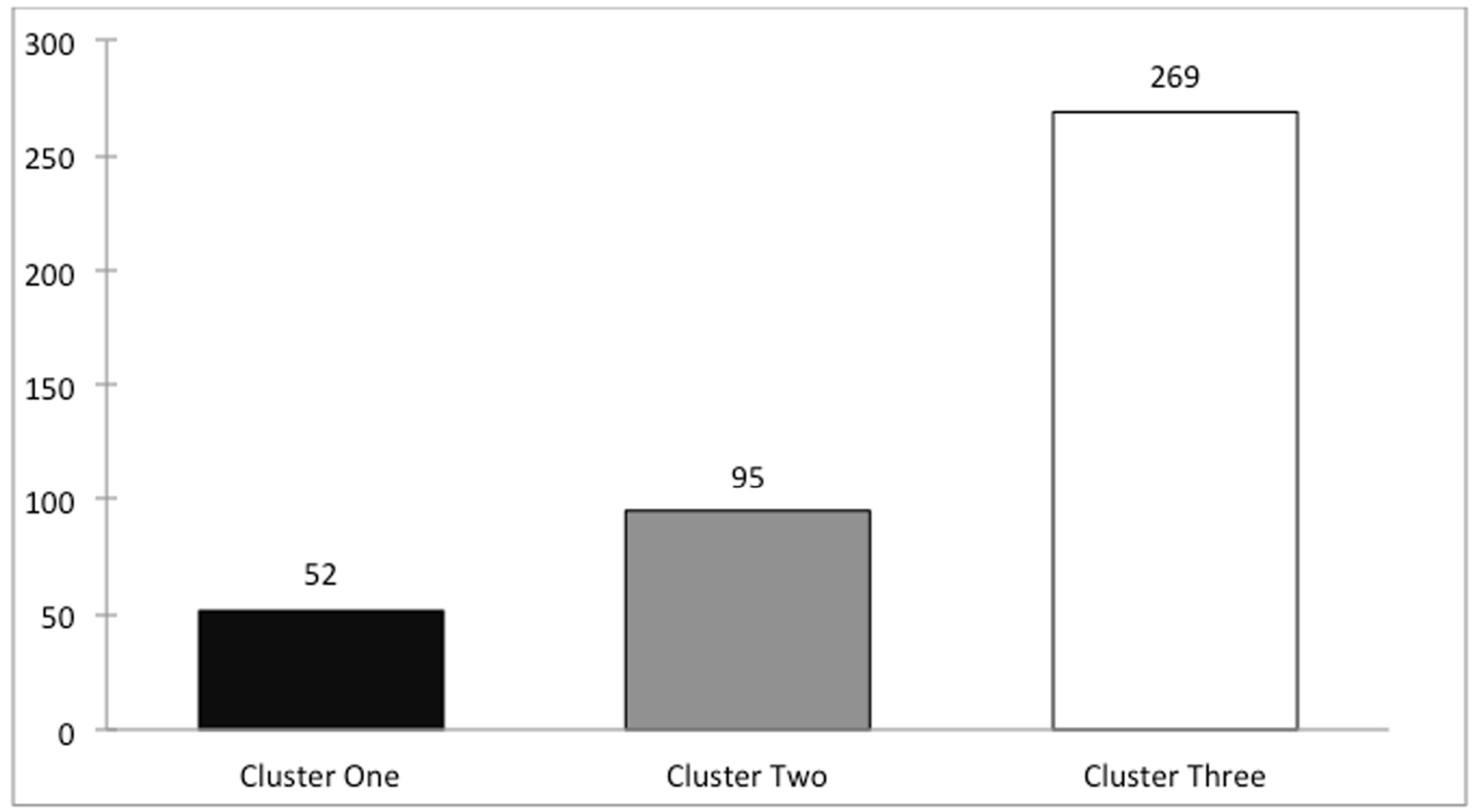

Figure 1. The frequency distribution of business by cluster group. Source: authors 


\begin{tabular}{|l|r|r|r|}
\hline \multicolumn{1}{|c|}{$\%$ of businesses at least quarterly... } & \multicolumn{3}{c|}{ Cluster } \\
\cline { 2 - 4 } & \multicolumn{1}{|c|}{ One } & \multicolumn{1}{|c|}{ Two } & 1.9 \\
\hline Measuring water consumption by customers & 82.7 & 52.6 & 1.1 \\
\hline Setting water-saving targets & 55.8 & 3.2 & 4.8 \\
\hline $\begin{array}{l}\text { Reviewing the performance of water-saving } \\
\text { devices }\end{array}$ & 63.5 & 9.5 & 1.9 \\
\hline Measuring energy consumption by customers & 92.3 & 88.4 & 3.3 \\
\hline Setting energy-saving targets & 75.0 & 10.5 & 8.9 \\
\hline $\begin{array}{l}\text { Reviewing the performance of energy-saving } \\
\text { devices }\end{array}$ & 80.8 & 20.0 & 0.7 \\
\hline Consider switching (to greener) energy suppliers & 13.5 & 0.0 & \\
\hline
\end{tabular}

n.b. Statistically significant differences in behaviour among clusters in terms of frequency of enacting each type of behaviour (Kruskal-Wallis Test, $\chi^{2}, 2 \mathrm{df}, \mathrm{p} \leq 0.05$ ).

Table 2. Variations in broad approaches to managing water and energy (clustering variables). Source: authors 


\begin{tabular}{|l|r|r|r|}
\hline \multirow{2}{*}{$\%$ of businesses that usually or always... } & \multicolumn{3}{|c|}{ Cluster } \\
\cline { 2 - 4 } & \multicolumn{1}{|c|}{ One } & \multicolumn{1}{|c|}{ Two } & Three \\
\hline Recycle biodegradable waste & 100.0 & 89.5 & 88.8 \\
\hline Recycle non-biodegradable waste & 98.1 & 95.8 & 96.3 \\
\hline Take energy-saving measures & 100.0 & 88.4 & 88.5 \\
\hline Purchase energy-saving devices & 100.0 & 89.5 & 87.4 \\
\hline Take water-saving measures & 94.2 & 64.2 & 62.5 \\
\hline Purchase water-saving devices & 78.8 & 60.0 & 56.1 \\
\hline Encourage our customers to save energy & 92.3 & 78.9 & 62.1 \\
\hline Encourage our staff to save energy & 94.2 & 78.9 & 69.5 \\
\hline Train staff in environmental management & & & 46.5 \\
issues & 86.5 & 60.0 & 26.0 \\
\hline Access external advice on environmental & & & 30.5 \\
management & 53.8 & & \\
\hline
\end{tabular}

n.b. Differences in behaviour among clusters statistically significant (Kruskal-Wallis Test, $\chi^{2}, 2 \mathrm{df}, \mathrm{p} \leq 0.05$ ) except for recycling non-biodegradable waste.

Table 3. Variations among clusters in enacting environmental initiatives. Source: authors 


\begin{tabular}{|c|c|c|c|}
\hline \multirow{2}{*}{ Attribute } & \multicolumn{3}{|c|}{ Cluster } \\
\hline & One & Two & Three \\
\hline $\begin{array}{l}\text { Number of Businesses* } \\
\text { (\% of sample) }\end{array}$ & $\begin{array}{c}52 \\
(12.5)\end{array}$ & $\begin{array}{c}95 \\
(22.8)\end{array}$ & $\begin{array}{r}269 \\
(64.7)\end{array}$ \\
\hline Number of employees (FTEs) & 5.3 & 3.4 & 2.7 \\
\hline Average number of bedspaces* & 45.7 & 21.0 & 13.3 \\
\hline Average turnover in 2009 (£k) & 66.4 & 74.1 & 53.8 \\
\hline$\%$ graded 4 -star or above & 69.3 & 62.7 & 66.2 \\
\hline $\begin{array}{l}\text { Average time in current ownership } \\
\text { (years) }\end{array}$ & 13.2 & 9.7 & 10.1 \\
\hline $\begin{array}{l}\% \text { concerned about negative effect } \\
\text { of climate change on business }\end{array}$ & 51.9 & 47.4 & 32.7 \\
\hline $\begin{array}{l}\text { \% committed to act on climate } \\
\text { change }\end{array}$ & 78.9 & 61.1 & 52.4 \\
\hline $\begin{array}{l}\text { Level of response to climate } \\
\text { change } \dagger\end{array}$ & 2.9 & 3.4 & 3.6 \\
\hline$\%$ of costs energy bills & 13.1 & 13.7 & 15.6 \\
\hline$\%$ of costs water bills & 8.1 & 6.5 & 6.6 \\
\hline $\begin{array}{l}\% \text { review energy bills six-monthly } \\
\text { or more }\end{array}$ & 61.5 & 58.9 & 37.9 \\
\hline $\begin{array}{l}\% \text { review water bills six-monthly } \\
\text { or more }\end{array}$ & 59.6 & 43.2 & 22.8 \\
\hline Average number of innovations & 10.7 & 8.9 & 7.5 \\
\hline $\begin{array}{l}\text { Average number of planned } \\
\text { innovations }\end{array}$ & 3.3 & 3.4 & 3.2 \\
\hline $\begin{array}{l}\text { Average total innovation } \\
\text { investment }(£ \mathrm{k})^{*}\end{array}$ & 21.0 & 17.7 & 10.3 \\
\hline $\begin{array}{l}\text { Environmental management as a } \\
\text { business priority (rank) }\end{array}$ & 3 & 6 & 6 \\
\hline $\begin{array}{l}\% \text { for whom utilities are major } \\
\text { feature in business planning }\end{array}$ & 71.2 & 73.7 & 55.2 \\
\hline $\begin{array}{l}\% \text { for whom tackling climate } \\
\text { change features in future }\end{array}$ & 67.3 & 56.8 & 36.6 \\
\hline
\end{tabular}




\begin{tabular}{|l|c|c|c|}
\hline investment plans & & & \\
\hline $\begin{array}{l}\text { Average preferred payback period } \\
\text { (years) }\end{array}$ & 5.6 & 5.3 & 5.1 \\
\hline
\end{tabular}

\section{$\underline{\text { Notes }}$}

* $5 \%$ trimmed mean

$\dagger 7$-point Likert Scale where $7=$ as far as we can, $1=$ not at all

Bold denotes statistically significant difference between the three clusters (Kruskal-Wallis Test, $\chi^{2}, 2 \mathrm{df}, \mathrm{p} \leq 0.05$; post-hoc analysis not possible).

Table 4. Selected business attributes among the three clusters. Source: authors 


\begin{tabular}{|l|r|r|r|}
\hline \multirow{2}{*}{$\%$ of reporting a decrease in... } & \multicolumn{3}{|c|}{ Cluster } \\
\cline { 2 - 4 } & One & \multicolumn{1}{|c|}{ Two } & Three \\
\hline Energy bills in the last 12 months & 24.0 & 11.2 & 13.6 \\
\hline Energy bills in the next 12 months & 15.7 & 11.0 & 10.8 \\
\hline Water bills in the last 12 months & 12.5 & 7.1 & 7.9 \\
\hline Water bills in the next 12 months & 7.8 & 3.4 & 1.6 \\
\hline Energy consumption in the last 12 & 40.0 & 18.2 & 19.3 \\
months & & & 11.8 \\
\hline Energy consumption in the next 12 & 23.5 & 17.2 & 11.0 \\
months & 21.7 & 18.3 & 4.4 \\
\hline Water consumption in the last 12 months & 18.0 & 5.6 & \\
\hline Water consumption in the next 12 months & & & \\
\hline
\end{tabular}

Table 5. Decreases as a feature in energy and water bills and consumption. Source: authors 


\begin{tabular}{|l|c|c|c|}
\hline \multicolumn{1}{|c|}{$\%$ of businesses who agreed that... } & \multicolumn{3}{c|}{ Cluster } \\
\cline { 2 - 4 } & One & Two & Three \\
\hline $\begin{array}{l}\text { Our environmental management actions benefit our } \\
\text { profitability }\end{array}$ & $\mathbf{7 1 . 1}$ & $\mathbf{6 5 . 2}$ & $\mathbf{4 4 . 4}$ \\
\hline $\begin{array}{l}\text { Managing our environmental impacts is morally the right } \\
\text { thing to do }\end{array}$ & $\mathbf{8 4 . 6}$ & $\mathbf{8 9 . 4}$ & $\mathbf{8 0 . 8}$ \\
\hline $\begin{array}{l}\text { Other businesses respond to climate change and we imitate } \\
\text { them }\end{array}$ & $\mathbf{1 2 . 3}$ & $\mathbf{2 2 . 4}$ & $\mathbf{2 7 . 5}$ \\
\hline $\begin{array}{l}\text { We manage our environmental impacts because our } \\
\text { utilities bills are soaring }\end{array}$ & $\mathbf{6 6 . 7}$ & $\mathbf{6 7 . 4}$ & $\mathbf{5 7 . 5}$ \\
\hline $\begin{array}{l}\text { There was a lack of information on how to respond to } \\
\text { climate change }\end{array}$ & $\mathbf{1 7 . 3}$ & $\mathbf{2 7 . 3}$ & $\mathbf{2 8 . 3}$ \\
\hline $\begin{array}{l}\text { There was too much conflicting information about climate } \\
\text { change and did not know where to begin* }\end{array}$ & 32.5 & 48.9 & 46.5 \\
\hline $\begin{array}{l}\text { Payback periods on new climate change solutions are too } \\
\text { long }\end{array}$ & $\mathbf{4 6 . 2}$ & $\mathbf{6 7 . 4}$ & $\mathbf{6 4 . 2}$ \\
\hline $\begin{array}{l}\text { Premises make it harder to introduce measures to tackle } \\
\text { climate change* }\end{array}$ & 53.8 & 65.3 & $\mathbf{7 0 . 6}$ \\
\hline to tackle climate change & 48.1 & 65.3 & $\mathbf{5 2 . 2}$ \\
\hline
\end{tabular}

Originally measured on five-point Likert Scales where $5=$ strongly agree, $3=$ neither agree nor disagree, 1 = strongly disagree. Bold denotes statistically significant difference between the three clusters (Kruskal-Wallis Test, $\chi^{2}, 2 \mathrm{df}, \mathrm{p} \leq 0.05$; $* \mathrm{p} \leq 0.10$; post-hoc analysis not possible).

Table 6. Selected attitudinal responses among the three clusters. Source: authors 


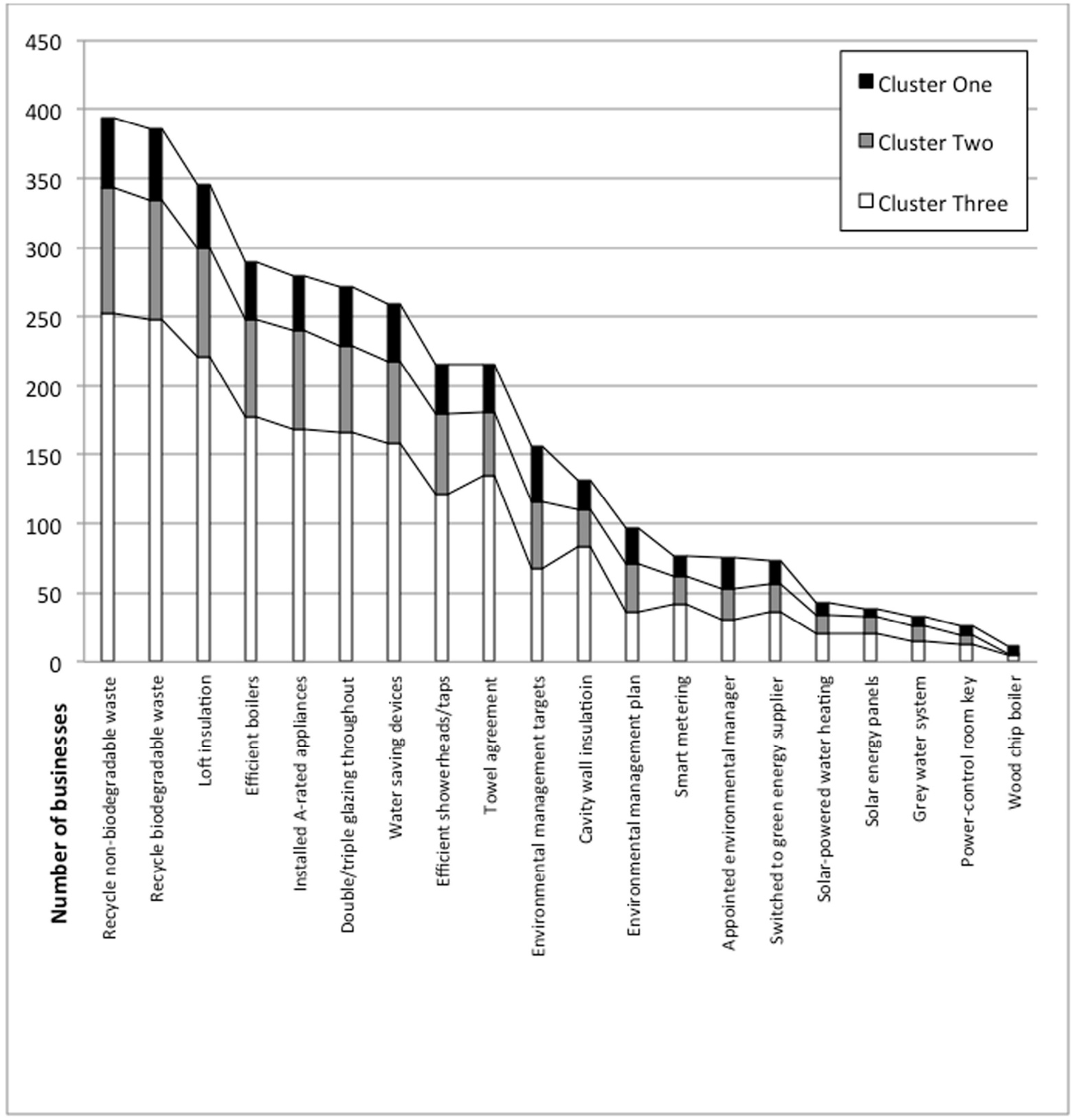

Figure 2. The implementation of specific environmental practices by cluster. Source: authors 


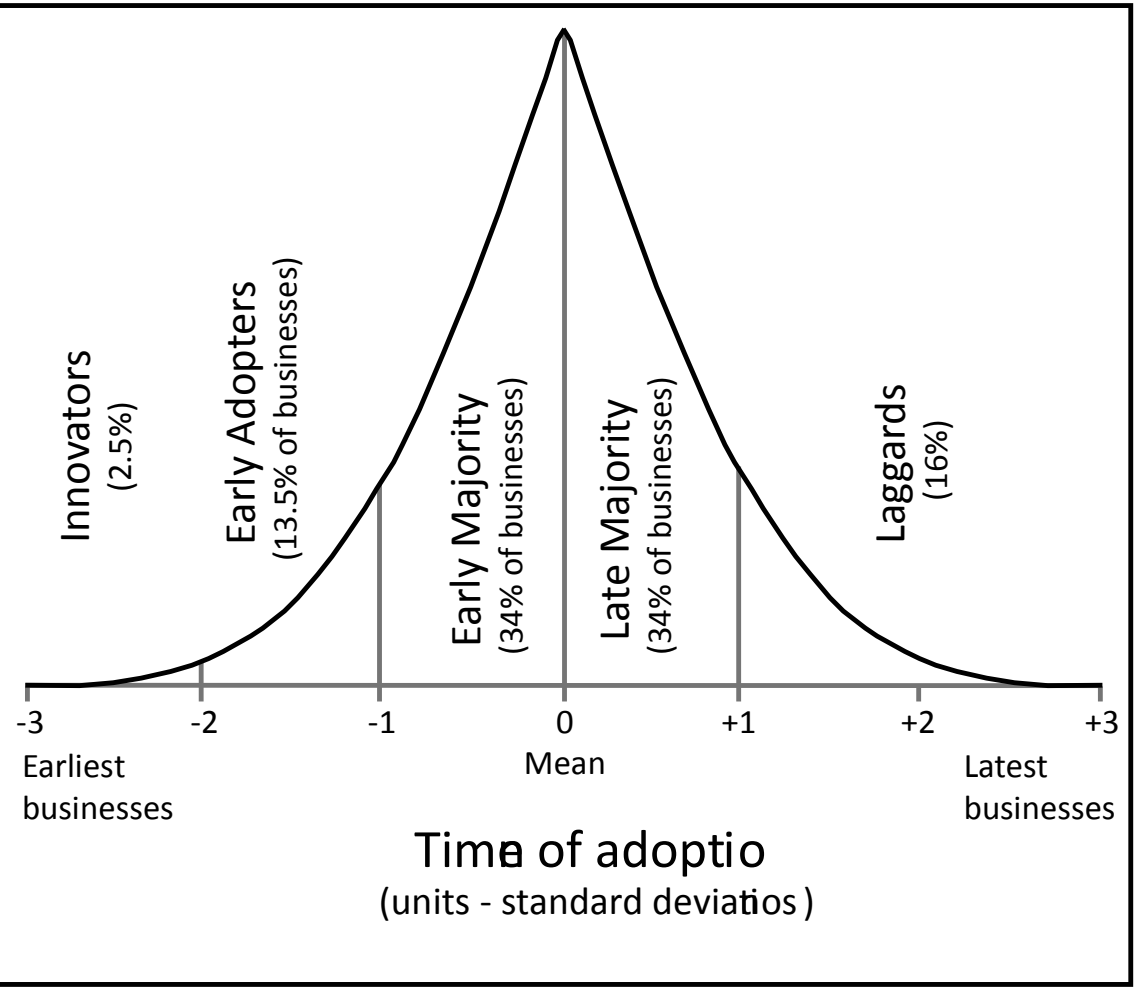

Figure 3. The Epidemic Model of the diffusion of innovation.

Source: data ranges from Robertson (1967), drawing authors. 